\title{
Tarsus as buckling material in retinal detachment surgery
}

\author{
ALY MORTADA \\ Department of Ophthalmology, Faculty of Medicine, University of Cairo, Egypt
}

The hazards of synthetic implants and the difficulty of obtaining other autogenous or homogenous implant material may be avoided by using the tarsus from the upper lid of the operated eye as buckling material in retinal detachment surgery, especially in cases of localized detachment with one or more tears. After the adherent conjunctival material has been removed, the tarsus tissue can be placed in a scleral pocket overlying the tear.

The size of the piece of tarsal tissue required depends on the size of the retinal tear and elevation of the detachment. The tarsus of the upper lid is about $10 \mathrm{~mm}$. in breadth, $29 \mathrm{~mm}$. in length, and $\mathrm{I} \mathrm{mm}$. in thickness (Duke-Flder and Wybar, I96r). One tarsus is usually sufficient. If there is vitreous retraction, two tarsi placed one above the other may be used to produce a very high buckle. If the retinal tear is long, two tarsi may be placed end to end. If the tear is small, only a small piece of tissue is needed. The tarsus may be folded before use. If the retinal tears are in different quadrants the tarsal tissue is placed in separate scleral pockets overlying the tears.

Fifteen cases of retinal detachment with tears have so far been operated upon using the fresh tarsus as buckling material.

Cases with fixed retinal folds, contracting membranes on the retinal surface, massive vitreous retraction, or re-operations that needed encircling bands were not treated in this way. Only when the retina was not replaced by rest was the subretinal fluid evacuated by one diathermy needle puncture not penetrating the retina. The Table shows five typical examples of operated cases.

Table Results in five typical cases

\begin{tabular}{|c|c|c|c|c|c|c|c|c|c|c|c|}
\hline $\begin{array}{l}\text { Age } \\
(y r s)\end{array}$ & Sex & Eye & $\begin{array}{l}\text { Refrac- } \\
\text { tion }\end{array}$ & $\begin{array}{l}\text { Dura- } \\
\text { tion } \\
\text { (wks) }\end{array}$ & $\begin{array}{l}\text { Reposition } \\
\text { of retina } \\
\text { by rest }\end{array}$ & Size and site of tear & & $\begin{array}{l}\text { Evacua- } \\
\text { tion of } \\
\text { sub- } \\
\text { retinal } \\
\text { fluid }\end{array}$ & $\begin{array}{l}\text { Size of tarsus } \\
\text { used }\end{array}$ & $\begin{array}{l}\text { Number } \\
\text { of } \\
\text { similar } \\
\text { opera- } \\
\text { tions }\end{array}$ & $\begin{array}{l}\text { Succes- } \\
\text { ses }\end{array}$ \\
\hline 30 & Male & $\mathbf{R}$ & $-4 \mathrm{D}$ & 8 & Positive & Horseshoe up and out & $1.5 \mathrm{~mm}$. & No & Half tarsus & 5 & 4 \\
\hline 40 & Male & $\mathbf{R}$ & $-9 D$ & 4 & Partial & Horseshoe up & $3 \mathrm{~mm}$. & No & All tarsus & 5 & 4 \\
\hline 25 & Male & $\mathbf{L}$ & $-{ }_{15} D$ & 2 & Negative & Horseshoe up and out & $4 \mathrm{~mm}$. & Yes & $\begin{array}{l}2 \text { tarsi one over } \\
\text { the other }\end{array}$ & $\mathbf{I}$ & $\mathbf{I}$ \\
\hline 35 & Male & $\mathbf{L}$ & $-2 \mathrm{D}$ & 3 & Negative & Dialysis $1-5$ o'clock & & No & $\begin{array}{l}2 \text { tarsi end to } \\
\text { end }\end{array}$ & I & - \\
\hline 42 & Male & $\mathbf{R}$ & $-6 \mathrm{D}$ & 2 & Partial & $\begin{array}{l}2 \text { horseshoe: up and } \\
\text { out, down and out }\end{array}$ & each $3 \mathrm{~mm}$. & Yes & $\begin{array}{l}2 \text { tarsi one in } \\
\text { each quadrant }\end{array}$ & 3 & 2 \\
\hline
\end{tabular}




\section{Discussion}

The scleral pocket operation using the tarsus as buckling material has the following advantages :

(I) A broad, smooth, high localized buckle of the diathermized sclero-choroid is produced to coapt with the retinal tear edges.

(2) There is no possibility of scleral erosion, as may occur with synthetic implants, such as polyethylene tubes (Regan and Schepens, 1963) or silicone (Smith and Zimmerman, 1965; Lincoff, Baras, and McLean, 1965), or of a string syndrome, as may occur with the encircling thread described by Arruga (1958).

(3) There is no infection or inflammatory reaction, such as may follow the use of polyviol (Custodis, 1952, 1956), polyethylene tubes (Schepens, Okamura, and Brockhurst, 1957), or silicone (Schepens, Okamura, Brockhurst, and Regan, 1960; McMeel and Wapner, 1965).

(4) The meibomian glands in the tarsus do not produce any inflammatory reaction even of the allergic type.

(5) There is no need for a major surgical procedure requiring the services of a general surgeon to obtain such tissue as auricular cartilage (Bailliart and Avrillon, 1964), fascia lata (Havener and Wachtel, 1964), or plantaris tendon (Crock and Galbraith, 1966).

(6) Scleral grafts placed in a scleral pocket (Paufique and Hervouet, I962; RodriquezVasquez, I962; Wilson, 1964; Knobloch and Cibis, 1965) require cadaver eyes and an eye-bank, which may not be available.

(7) Tarsectomy is an easy operation not followed by ptosis.

(8) This method avoids the risk of a further operation which may be needed to remove a synthetic implant in case of protrusion, inflammatory reaction, pain in the eye, headache, or heterophoria.

(9) Diathermy cautery over a thin scleral lamella avoids the hazards of excessive cautery, and the non-cauterized external flap minimizes scleral post-operative adhesions to Tenon's capsule.

(10) Coaptation of the diathermized choroid and retina at the edges of the tear prevents the formation of subretinal fluid, or the postoperative accumulation of fluid through exudative choroiditis.

(1I) The patient is able to get up on the 7 th postoperative day.

(12) The operation is successful in 73 per cent. of cases.

\section{Summary}

(r) Aiming at a localized broad sclero-choroid buckle at the site of the retinal break, without the use of synthetic implants and without the risks involved in obtaining other autogenous or homogenous materials, the fresh tarsus is placed in a scleral pocket.

(2) Indications and advantages of the operation are described.

(3) Fifteen such cases have so far been operated on by this method and eleven were successful. 


\section{References}

ARruga, H. (1958) Bull. Soc. franc. Ophtal., 71, 57 I

Bailliart, J. P., and AVRillon, J. (1964) Ibid., 77, 6I5

CROCK, G. W., and GAlBraith, J. E. K. (1966) Brit. J. Ophthal., 50, 517

Custodis, E. (1952) Ber. dtsch. ophthal. Ges., 195 I, 57, 227 (1956) Klin. Mbl. Augenheilk., 129, 476

DUKE-ELDER, s., and WYBAR, K. (196i) "System of Ophthalmology", ed. S. Duke-Elder, vol. 2, p. 5 18. Kimpton, London

haVENer, W. A., and Wachtel, J. G. (1964) Amer. F. Ophthal., 57, 201

KNOBLOCH, W. H., and CIBIS, P. A. (1965) Ibid., 60, I91

Lincoff, H. A., Baras, I., and mclean, J. (1965) Arch. Ophthal. (Chicago), 73, i6o

MCMEEL, J. W., and WAPNER, J. M. (1965) Ibid., 74, 42

PaufiQue, L., and hervouet, F. (1962) Ann. Oculist. (Paris), 195, 385

REgan, C. D. J., and schepens, c. L. (1963) Trans. Amer. Acad. Ophthal. Otolaryng., 67, 335

RODRIGUEZ-VASQUEZ, F. (1962) Amer. F. Ophthal., 53, 937

SChEPENS, C. L., OKAMURA, I. D., and BROCKHURST, R. J. (1957) A.M.A. Arch. Ophthal., 58, 797

$\longrightarrow,-,-$, and REGAN, C. D. J. (1960) Arch. Ophthal. (Chicago), 64, 868

SMITH, M. E., and ZimMERMAN, L. E. (1965) Ibid., 73, 618

WILSON, F. M. (1964) Ibid., 72, 2 I 2 